\title{
Morphological Alterations in the External Gills of Some Tadpoles in Response to $\mathrm{pH}$
}

\author{
Caressa Maebha Thabah ${ }^{1}$ Longjam Merinda Devi ${ }^{1}$ Rupa Nylla Kynta Hooroo ${ }^{1}$ Sudip Dey ${ }^{2}$ \\ 1 Developmental Biology Laboratory, Department of Zoology, North- \\ Eastern Hill University, Shillong, Meghalaya, India \\ 2 Electron Microscope Laboratory, Sophisticated Analytical Instrument \\ Facility, North-Eastern Hill University, Shillong, Meghalaya, India

\begin{abstract}
Address for correspondence Caressa Maebha Thabah, PhD in Zoology, Developmental Biology Laboratory, Department of Zoology, North-Eastern Hill University, Shillong 793022, Meghalaya, India (e-mail: caressathabah26@gmail.com).
\end{abstract}

J Morphol Sci 2018;35:142-152.

\begin{abstract}
Keywords

- Hyla annectans

- Euphlyctis cyanophlyctis

- low pH

- high pH

- scanning electron microscopy

Introduction Water $\mathrm{pH}$ affects the breeding, hatching, development, locomotion, mortality and habitat distributions of species in nature. The external gills of anuran tadpoles were studied by several authors in relation to abiotic factors. Exposure to low and high $\mathrm{pH}$ has been found to adversely affect the different tissues of various organisms. On that consideration, the present investigation was performed with tadpoles of the species Hyla annectans and Euphlyctis cyanophlyctis.

Material and Methods The maximum and the minimum $\mathrm{pH}$ thresholds were determined prior to the detailed experiments on the effects of $\mathrm{pH}$. The $\mathrm{pH}$ that demonstrated $50 \%$ mortality was taken as the minimum and maximum $\mathrm{pH}$ thresholds. The hatchlings of both the species were then subjected to different $\mathrm{pH}$ (based on the minimum and maximum $\mathrm{pH}$ thresholds). After 48 hours of exposure, the external gills of the hatchlings were anesthetized and observed under a scanning electron microscope.

Results After 48 hours, clumping, overlapping and curling of the secondary filaments of the external gills and epithelial lesions in response to both acidic and alkaline $\mathrm{pH}$ were observed. The lengths of the secondary filaments were also affected by $\mathrm{pH}$ in both the species studied when compared with the control groups.

Conclusion Scanning electron microscopic approaches are relevant in assessing the adverse effects of $\mathrm{pH}$ on the morphology of the external gills of $H$. annectans and $E$. cyanophlyctis tadpoles, which included problems with osmoregulation, acid-base balance and respiratory function.
\end{abstract}

\section{Introduction}

Over the past few years, the understanding of the effects of acidification on amphibians has increased, as this is the main group of organisms potentially affected by the acidification of fresh water systems. ${ }^{1}$ Amphibians mostly breed in small shallow ponds or in the stagnant littoral zone of large water bodies, in which they may encounter increasing levels of environmental stresses, like acidification. ${ }^{2}$ Most anuran tadpoles use aquatic habitats for their growth, development and metamorphosis. During the different developmental periods, an increase in hydrogen ion concentration may bring forth several effects: decreased sperm motility, ${ }^{3}$ increased embryonic mortality, and reduced hatchability. ${ }^{4,5}$ Further, tadpoles exhibit an array of sublethal responses to increased hydrogen ion concentration, such as alterations in growth and development or morphological defects, especially after hatching. ${ }^{6-9}$ Amphibian larvae are affected by acidic pH through different mechanisms, and one of the consequences of this is a change in the ionic equilibrium..$^{10,11}$ In anuran tadpoles, the gills not only perform the respiratory function but they also are the sites for received

March 3, 2017

accepted

August 3, 2018

published online

August 31, 2018
DOI https://doi.org/

10.1055/s-0038-1669476. ISSN 2177-0298.
Copyright (e 2018 by Thieme Revinter

Publicações Ltda, Rio de Janeiro, Brazil
License terms

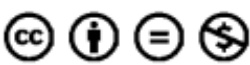


ion exchange. ${ }^{12}$ The respiratory gill apparatus of anuran tadpoles is distinguished by two modes of development that are determined by their position as internal and external gills. ${ }^{13}$ All gills and their associated structures are external before the opercular fold is formed. There is a variation among the anurans in relation to the stage of the development at hatching, which indicated that the external gills are fully developed only for a short period of time after hatching. ${ }^{14}$ Thus, it would be inappropriate to consider the external gills as having a negligible function in anurans. The anuran gill apparatus is considered a multifunctional organ, ${ }^{13}$ and alterations in the water can bring about a change in its morphology and functions resulting from altered physiological and metabolic processes such as respiration, osmoregulation and acid-base balance. ${ }^{15}$

Hyla annectans has a tendency to breed in pristine habitats away from stressful environments, such as human settlements, construction sites etc. Euphlyctis cyanophlyctis, on the other hand, breeds in quiet or stressful environments, and thrives well in these habitats. During the breeding season, the larvae of both species were found to inhabit waters with $\mathrm{pH}$ that ranges from low to slightly high. In general, the $\mathrm{pH}$ of water has been reported to be high in the winter months and low in the monsoon season and summer in India. During summer, low pH is caused by high turbidity resulting from heavy rain, algal blooms, human activity etc. $^{16,17}$ The increased temperature promotes microbial activities that cause a rise in the production of $\mathrm{CO}_{2} \cdot{ }^{16,17}$ During winter, high $\mathrm{pH}$ could be attributed to increased primary productivity. The high growth of algal population due to increased $\mathrm{CO}_{2}$ leads to an increase in the pH levels. ${ }^{18}$ Anuran external gills were chosen for this investigation because they were in direct contact with the aquatic environment. Further, after hatching, the external gills only last for a short time ( 72 hours) before they start to regress. Hence, the external gills play a major role as an indicator of water quality. Anuran gills that were exposed to varying $\mathrm{pH}$ conditions are likely to exhibit morphological changes that, in turn, could affect the physiology of the animal. In the present study, the effects of low and high $\mathrm{pH}$ on the morphological features of the external gills of two anuran species belonging to two different families, a tree frog, $H$. annectans, and a skipper frog, E. cyanophlyctis, which breed during the early part of the monsoon season, were analyzed.

\section{Materials and Methods}

\section{Study Materials}

Hyla annectans

Hyla annectans, a species of the genus Hyla described by Laurenti in 1768 , is the only species of this genus found in India. ${ }^{19}$ It has been recorded in Meghalaya, Nagaland and upper Burma. ${ }^{20}$ It breeds from March to June, and is categorized as a lower-risk near threatened species. ${ }^{21}$ This species inhabits temporary ponds, rain pools, puddles and terraced paddy fields at the edge of the forest, where water logging is observed. The tadpoles of this species ( - Fig. 1 ) are found till the month of July.

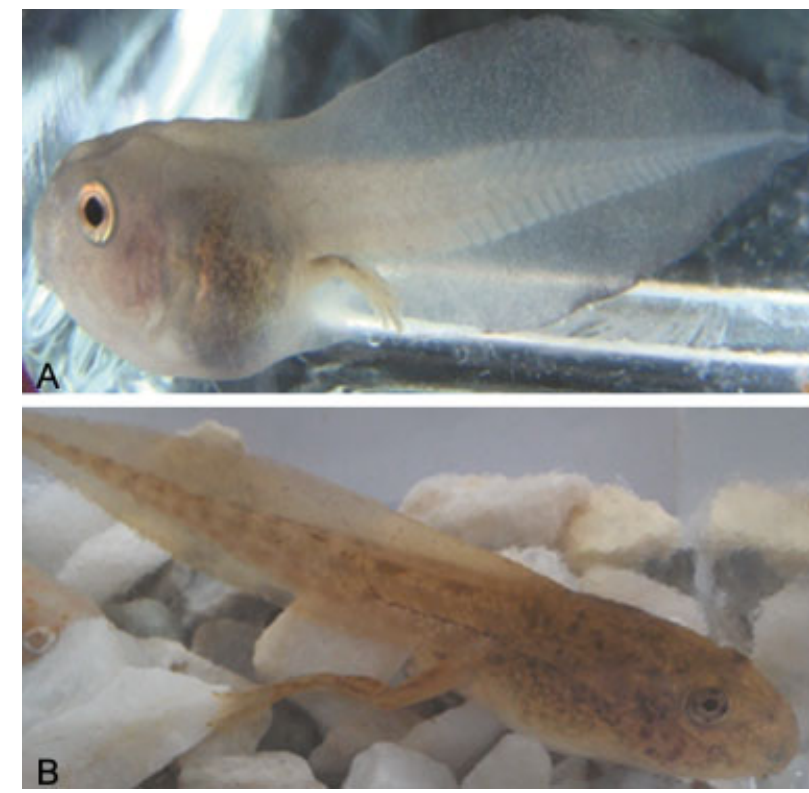

Fig. 1 (A) Lateral view of Hyla annectans tadpole at stage 39. (B) Lateral view of Euphlyctis cyanophlyctis tadpole at stage 39.

\section{Euphlyctis cyanophlyctis}

Euphlyctis cyanophlyctis belongs to the family Dicroglossidae (Anura, Amphibia). It is distributed all over India, Pakistan, Bangladesh, Sri Lanka, Nepal and Thailand. ${ }^{20}$ It breeds from March to August. The tadpole has an olive to gray brown body, with loosely scattered black pigmentation. It can tolerate a wide range of oxygen, temperature and $\mathrm{pH}$ variations, from fresh water to considerably brackish and polluted refuse water.

\section{Collection of Eggs}

The eggs of $H$. annectans used in the study were collected from a temporary pool in Sohra (Cherrapunjee) Meghalaya, India (altitude of $4,869 \mathrm{ft}$ above sea level [ASL]). The eggs of E. cyanophlyctis were collected from a paddy field in the Ri Bhoi district, Meghalaya, (altitude of 2,916 ft ASL). The eggs were collected with the help of a close mesh and were transported to the laboratory, where they were kept in plastic trays filled with pond water under room temperature.

\section{Determination of Maximum and Minimum pH Thresholds}

The eggs of both species were exposed to different levels of low $\mathrm{pH}(3.0 ; 3.5 ; 4.0 ; 4.5 ; 5.05 .5$; and 6.0$)$ and high $\mathrm{pH}(7.5 ; 8.0$; $8.5 ; 9.0 ; 9.5 ; 10.0$; and 10.5 ) to test the maximum and minimum threshold $\mathrm{pH}$ they could withstand. The control groups of tadpoles were maintained in water collected from their natural habitat with a $\mathrm{pH}$ of 6.5 for both species. The $\mathrm{pH}$ at which $50 \%$ mortality occurred was taken as the minimum and maximum $\mathrm{pH}$ thresholds for the tadpoles. The experiments were performed at a $\mathrm{pH}$ level higher than the minimum threshold and lower than the maximum threshold. The $\mathrm{pH}$ level was measured with an APX 175 digital pH meter (CD 
Hightech Pvt. Ltd., Malleswaram, Bangalore, India) with automatic temperature compensation. The developmental stage was determined through appropriate developmental chronological tables. ${ }^{22}$

\section{Experiment on Hatchlings}

The embryos of both species were reared up to stage 19, a stage in which the gill buds are formed. The experimental groups for low $\mathrm{pH}$ were maintained in water in which the $\mathrm{pH}$ was adjusted by adding dilute $\mathrm{HCl}$. For the high $\mathrm{pH}$ group, water was made alkaline with the addition of dilute $\mathrm{NaOH} .{ }^{23}$ The $\mathrm{pH}$ was adjusted to 4.5 and 8.5 for $H$. annectans, and to 3.5 and 9.5 for E. cyanophlyctis respectively (based on the minimum and maximum $\mathrm{pH}$ thresholds). The tadpoles were maintained for $\sim 48$ hours, till they attained stage 22 to $23^{22}$ in the laboratory. After 48 hours of exposure to low and high $\mathrm{pH}$, the hatchlings were anaesthetized with tricaine methanesulfonate (MS-222; Sandoz, Sigma-Aldrich, St. Louis, MO), ${ }^{24}$ and were processed for optical and scanning electron microscopy (SEM).

\section{Optical Microscopy}

For light microscopy, the external gills were fixed in a 1:1 solution of formaldehyde and ethanol. The observations were made with a Leica ES2 microscope (Leica Microsystems, Wetzlar, Germany), and were photographed using a Nikon Coolpix S3200 16.0 Mp 6X wide optical zoom camera (Nikon, Minato, Tokyo, Japan).

\section{Scanning Electron Microscopy}

For the SEM, the specimens were fixed in $2.5 \%$ glutaraldehyde in $0.1 \mathrm{M}$ sodium cacodylate buffer $(\mathrm{pH} 7.2)$ for 4 hours at $4^{\circ} \mathrm{C}$. Following the primary fixation, the tissues were washed for 15 to 30 minutes in sodium cacodylate buffer. The postfixation was performed with $1 \%$ osmium tetroxide prepared in $0.1 \mathrm{M}$ sodium cacodylate buffer ( $\mathrm{pH} 7.2$ ), and the tissues were dehydrated in graded acetone with 2 changes of 15 to 30 minutes in each grade. The dehydrated samples were dried using the tetramethylsilane (TMS) drying technique of Dey et al. ${ }^{25}$ The samples were secured horizontally to brass stubs $(10 \mathrm{~mm}$ in diameter by $30 \mathrm{~mm}$ in height) with double adhesive tape. A conductive coating of gold was applied to the samples using the JFC 1100 (JEOL Ltd., Akishima, Tokyo, Japan) ion sputter. A relatively low vacuum was maintained in the sputtering chamber for the ionization of air particles, which was followed by the application of high voltage. The ionized air particles, while moving randomly, hit the target metal (gold), resulting in the release of fine gold particles that coat the samples. Gold coating prevents sample damage due to radiation, and also increases the conductivity. The observations were made with a JSM 6360 (JEOL Ltd., Akishima, Tokyo, Japan) scanning electron microscope in the secondary electron emission mode at an accelerating voltage of $20 \mathrm{KV}$, and at a working distance of $12 \mathrm{~mm}$.

\section{Statistical Analysis}

All data are presented as means \pm standard error (SE). The relationships within each treatment were assessed by oneway analysis of variance (ANOVA), followed by Tukey multi- ple comparison tests. A significance level of $p \leq 0.05$ was used.

\section{Results}

\section{The Minimum and Maximum pH Thresholds}

The minimum $\mathrm{pH}$ threshold for the $H$. annectans tadpoles was 4.0 , with a mortality rate of $80 \%$, and the maximum $\mathrm{pH}$ threshold was 9.0, with a mortality rate of $60 \%$. The minimum $\mathrm{pH}$ threshold level for the E. cyanophlyctis tadpoles was 3.0 , with a mortality rate of $70 \%$, and the maximum $\mathrm{pH}$ threshold was 10.0 , with a mortality rate of $70 \%$. No mortality occurred in the control groups of each species, which were maintained at a $\mathrm{pH}$ of 6.5 during the experimental period.

\section{Morphology of the Gills}

\section{Light Microscopy}

Three days after fertilization, the embryos of both the species attained stage 20,22 which is defined by gill circulation and tail elongation. The development of the external gills in both species reached its peak at stage 23 (Gosner, 1960), ${ }^{22}$ and the gills at this stage were chosen for the morphological study, as they begin to regress 3 days after that. The observations made with light microscopy on the external gills of both species revealed a pair of well-developed branched gill filaments. They are present laterally on each side of the tadpole, posterior to the head ( - Fig. 2A, B).

\section{Scanning Electron Microscopy \\ Control group (pH 6.5) \\ Hyla annectans tadpoles}

Scanning electron microscopy of the external gills in the control group (6.5) of $H$. annectans tadpoles revealed

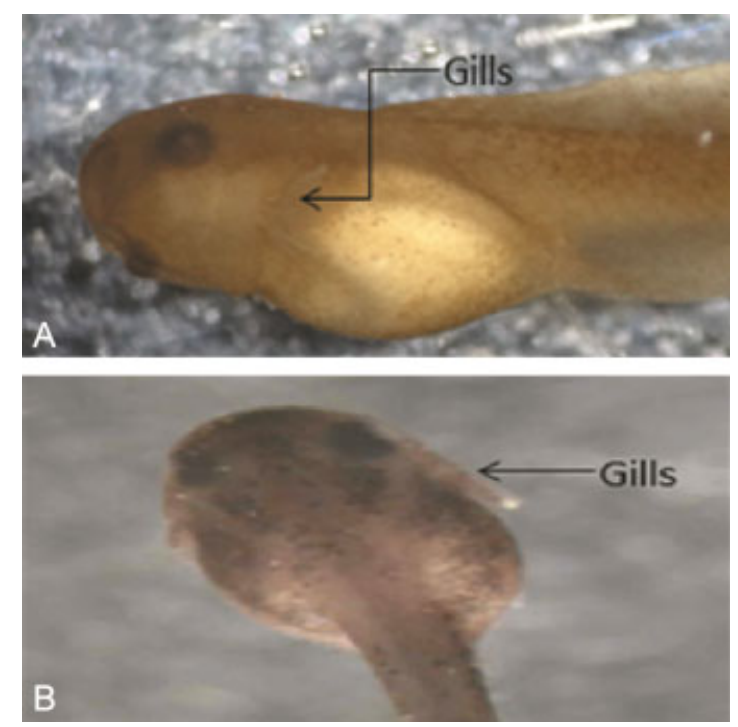

Fig. 2 (A) Lateral view of the external gills of Hyla annectans larvae at stage 23 (B) Dorsal view of the external gills of Euphlyctis cyanophlyctis larvae at stage 23. 

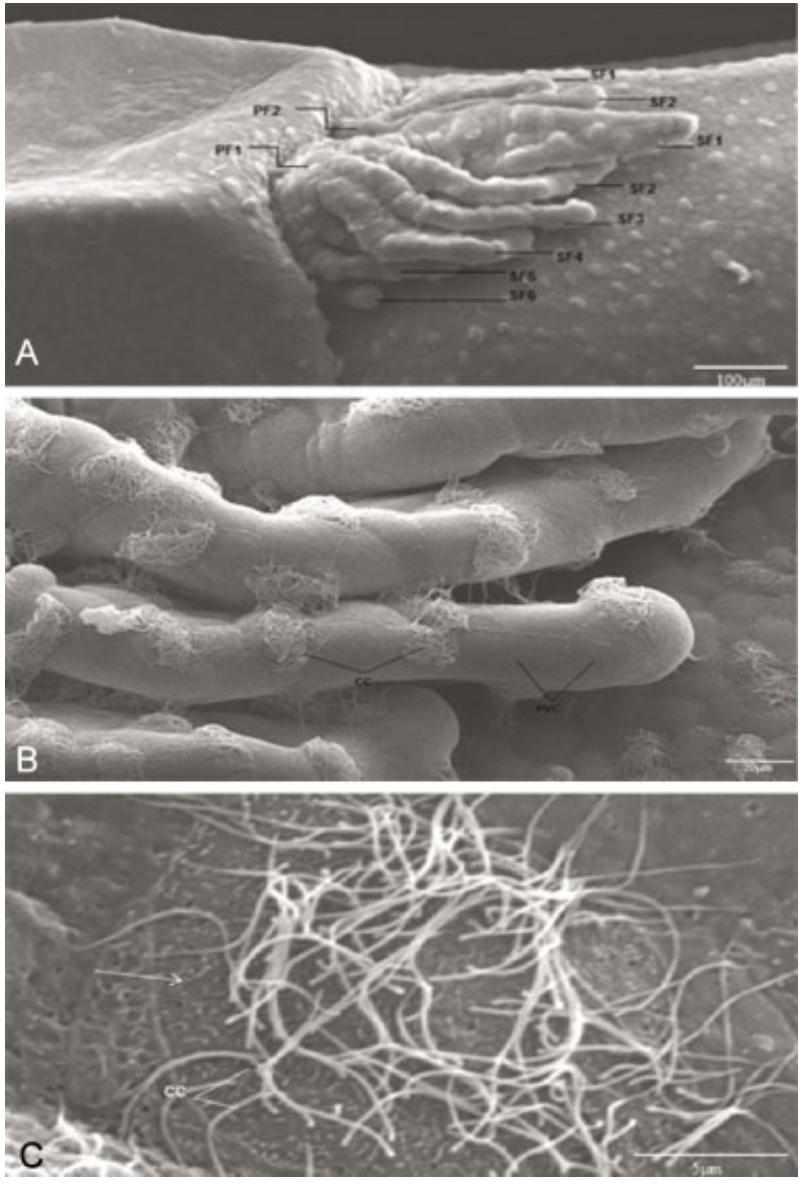

Fig. 3 (A) Scanning electron micrographs showing the morphology of the external gills of Hyla annectans tadpoles, under control conditions, comprising the primary filaments (PF1 and PF2) and the secondary filaments (SF1 to SF6). (B) Scanning electron micrographs showing the pavement cells (PVCs) and the ciliated cells (CCs) in $H$. annectans tadpoles. (C) Scanning electron micrographs showing the CCs and the microridges (arrow) in $\mathrm{H}$. annectans tadpoles.

that it consists of 2 main primary filaments, and each primary filament is made of 2 to 6 secondary filaments ( - Fig. 3A). The epithelium of the gill filaments observed with SEM is composed of two types of cells; the polygonal cells, known as pavement cells, which represent the most frequent cellular types with well-developed boundaries, and the ciliated cells, which are less common when compared with the pavement cells (-Fig. 3B). They bear long tufts of cilia, which often extend above the pavement cells. Pavement cells and ciliated cells are characterized by the presence of short superficial microridges (-Fig. 3C).

\section{Euphlyctis cyanophlyctis tadpoles}

The external gills of E. cyanophlyctis, on the other hand, are composed of two primary filaments with 5 to 6 welldeveloped secondary filaments arising from each primary filament (-Fig. 4A). The morphological features of the external gills of these tadpoles were observed to be similar to those of the $H$. annectans tadpoles. The epithelium is composed of cells known as the pavement cells, and ciliated cells. Microridges were also observed ( - Fig. 4B, C).
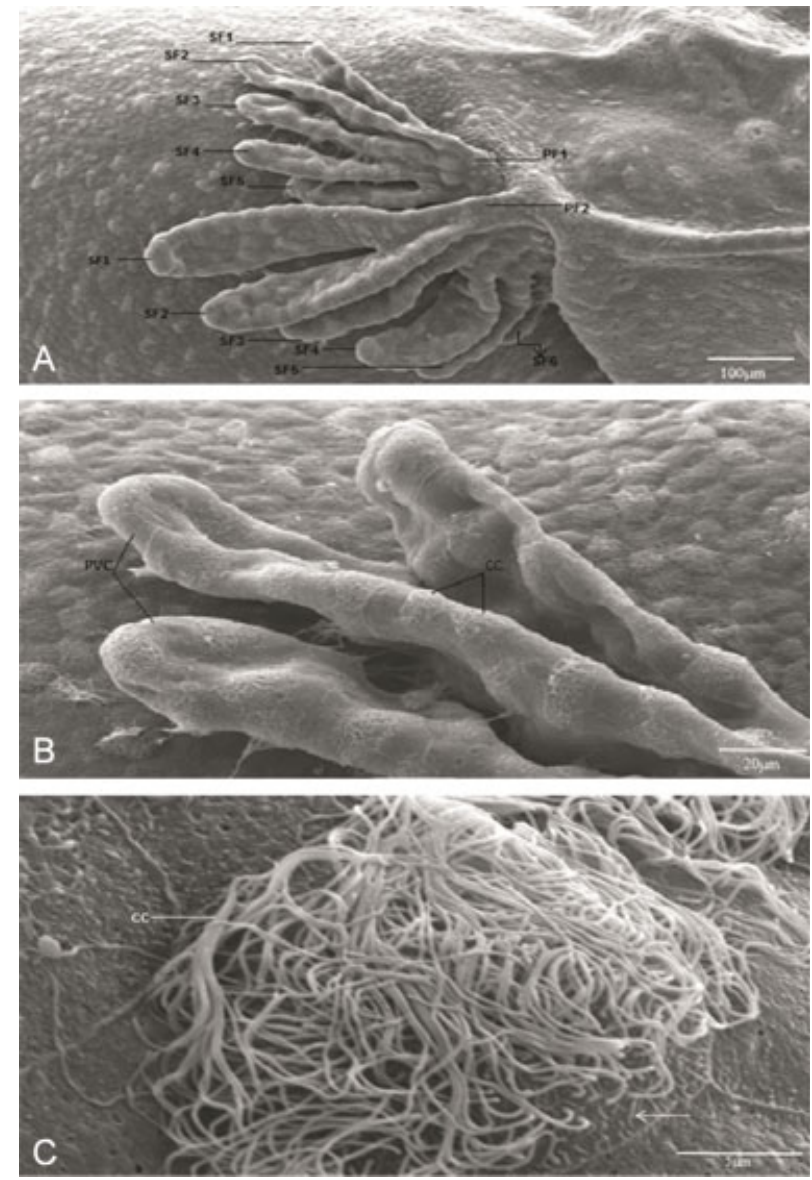

Fig. 4 (A) Scanning electron micrographs showing the morphology of the external gills of Euphlyctis cyanophlyctis tadpoles, under controlled conditions, comprising the primary filaments (PF1 and PF2) and the secondary filaments (SF1 to SF6). (B) Scanning electron micrographs showing the ciliated cells (CCs) and the pavement cells (PVCs) in E. cyanophlyctis tadpoles. (C) Scanning electron micrographs showing the CCs and the microridges (arrow head).

\section{Experimental groups}

The gill apparatus of the tadpoles of both species that were reared in water with low and high pH did not reveal any morphological changes when compared with the control groups after 24 hours of exposure. However, microstructural modifications occurred in the external gills only after 48 hours of exposure.

\section{Low $\mathrm{pH}$ group (4.5)}

\section{Hyla annectans tadpoles}

Scanning electron microscopy revealed a reduction in the length of the secondary filaments and clumping of the adjacent filaments at certain places ( $\mathbf{F i g . 5 A}, \mathbf{9}, \mathbf{- T a b l e} \mathbf{1}$ ). The pavement cells exhibited a distinctive swelling appearance (-Fig. 5B). The breakage of cilia at certain places and the occurrence of epithelial lesions were also observed (-Fig. 5C).

\section{Low $\mathrm{pH}$ group (3.5)}

\section{Euphlyctis cyanophlyctis tadpoles}

After exposure to low $\mathrm{pH}$, it was revealed that the morphology and orientation of the gill filaments was disturbed. An overlapping of the secondary filaments was evident when 

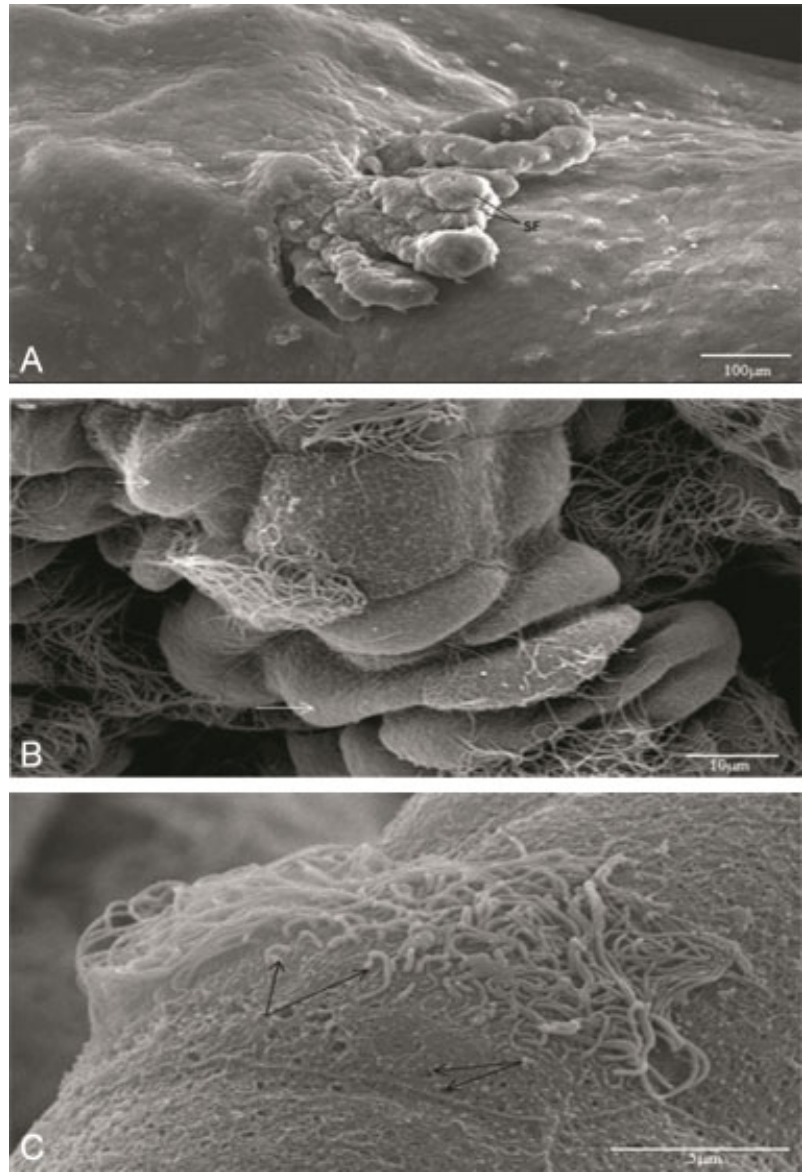

Fig. 5 (A) Scanning electron micrographs of Hyla annectans larvae after 48 hours of exposure to low $\mathrm{pH}$ showing the reduction in the length and clumping of adjacent secondary filaments (SFs). (B) Scanning electron micrographs showing the swelling of the pavement cells (arrow) under low $\mathrm{pH}$. (C) Scanning electron micrographs showing breakage of the cilia and epithelial lesions under low pH (arrow).

compared with the control group ( - Fig. 6 A). The gills revealed swellings in the pavement cells and breakage of the cilia at certain places ( $\mathbf{F i g}$. 6B). Epithelial lesions were also evident ( - Fig. $\mathbf{6 C}$ ). There was no significant increase or decrease in the length of the secondary filaments in the tadpoles maintained in water with a low $\mathrm{pH}(p>0.05)$ when compared with the control group. (-Table 1; - Fig. 9B).

\section{High pH group (8.5)}

\section{Hyla annectans tadpoles}

At a higher $\mathrm{pH}$ (8.5), morphological changes were also observed in the gill tufts of $H$. annectans tadpoles, and
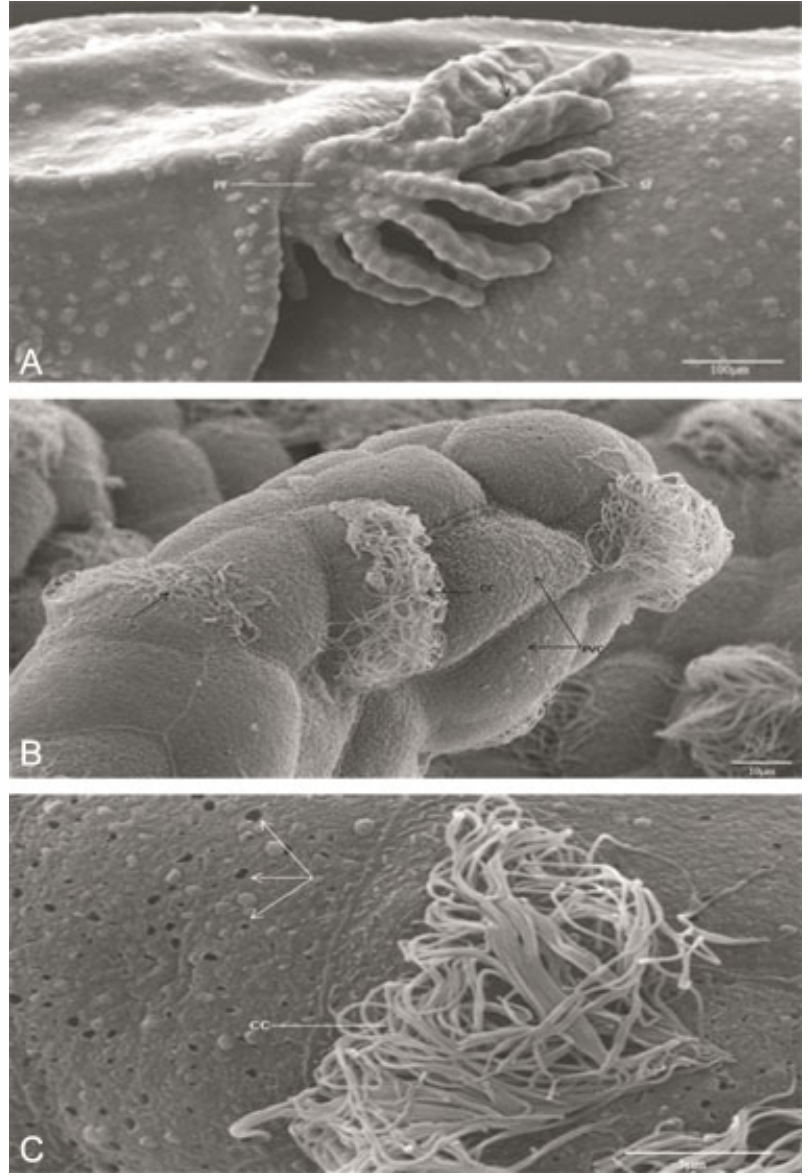

Fig. 6 (A) Scanning electron micrographs of the external gills of Euphlyctis cyanophlyctis larvae after 48 hours of exposure to low $\mathrm{pH}$ showing the primary filament (PF) and the secondary filaments (SFs) along with the overlapping filaments (arrow). (B) Scanning electron micrograph showing the morphology of the swellings of the ciliated cells (CCs) on the pavement cells (PVCs). Breakage of the CCs was also observed at certain places (arrow). (C) Scanning electron micrographs showing the morphology of the CCs and the epithelial lesions (arrow).

some of the secondary filaments exhibited a curling and enfolding effects ( - Fig. 7A ). The pavement cells were swollen in certain portions along the secondary filament. On the other hand, the ciliated cells maintained their original structural features. However, swellings of the

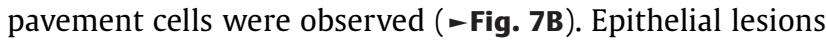
were also observed at certain places ( $\mathbf{- F i g . ~} \mathbf{7 C}$ ). There was no significant increase or decrease in the length of

Table 1 Mean length (in $\mu \mathrm{m}$ ) of the secondary filaments of Hyla annectans and Euphlyctis cyanophlyctis tadpoles under the effects of low and high $\mathrm{pH} \pm$ standard error (SE)

\begin{tabular}{|l|l|l|l|l|l|}
\hline Observations & $\mathrm{N}$ & $\begin{array}{l}\text { Hyla } \\
\text { annectans }\end{array}$ & Observations & $\mathrm{N}$ & Euphlyctis cyanophlyctis \\
\hline Control (6.5) & 5 & $237.68 \pm 20.38$ & Control (6.5) & 5 & $199.22 \pm 17.21$ \\
\hline Low pH (4.5) & 5 & $140.76 \pm 14.76$ & Low pH (3.5) & 5 & $179.99 \pm 14.39$ \\
\hline High pH (8.5) & 5 & $240.75 \pm 25.74$ & High pH (9.5) & 5 & $263.83 \pm 17.01$ \\
\hline
\end{tabular}

Abbreviation: $\mathrm{N}$, number of secondary filaments. 

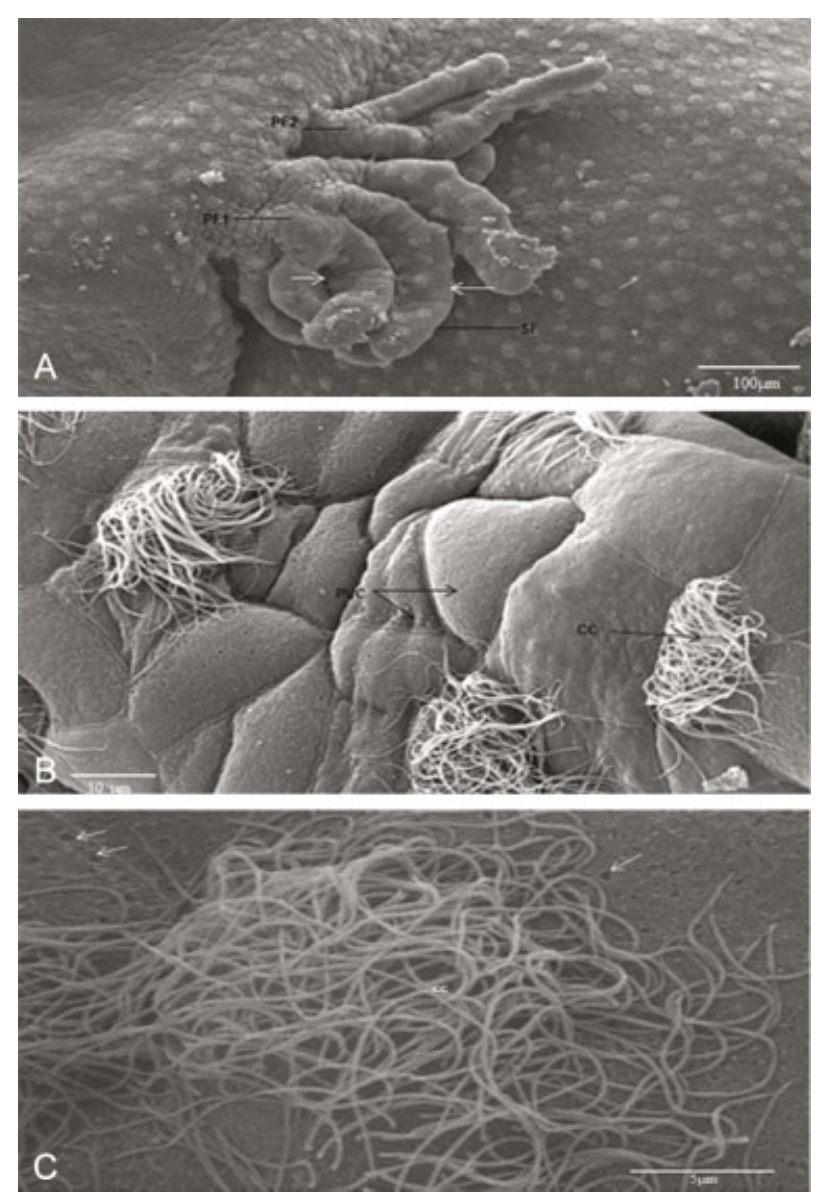

Fig. 7 (A) Scanning electron micrographs of the external gills of Hyla annectans tadpoles showing the curling and enfoldings (arrow) of the secondary filaments (SFs) after 48 hours of exposure to high pH. (B) Scanning electron micrographs showing swellings of the pavement cells (PVCs) on portions of the SFs along with the morphology of the ciliated cells (CCs). (C) Scanning electron micrographs showing the CCs and the epithelial lesions (arrow).

the secondary filaments of the tadpoles maintained in water with a high $\mathrm{pH}(p>0.05)$ compared with the control group (-Table 1; - Fig. 9A).

\section{High pH group (9.5)}

\section{Euphlyctis cyanophlyctis tadpoles}

At a higher $\mathrm{pH}$ (9.5), the secondary filaments of E. cyanophlyctis tadpoles were observed to be overlapped, and tips of the secondary filaments were bent toward one another at certain portions ( $\mathbf{- F i g . ~ 8 A )}$ ). The boundaries of the adjacent pavement cells were also affected to the point that their demarcation could not be distinguished ( - Fig. 8 8B). The morphology of the ciliated cells remained unaffected. However, epithelial lesions throughout the surface of the secondary filament were evident ( $\mathbf{- F i g . ~ 8 C )}$ ). There was a significant increase $(p<0.05)$ in the length of the secondary filaments when compared with the control group (-Table 1, - Fig. 9B).

The similarities and differences in gross morphology and micro structural features of various components of the external gill apparatus of the two species of tadpoles are shown in - Table 2.
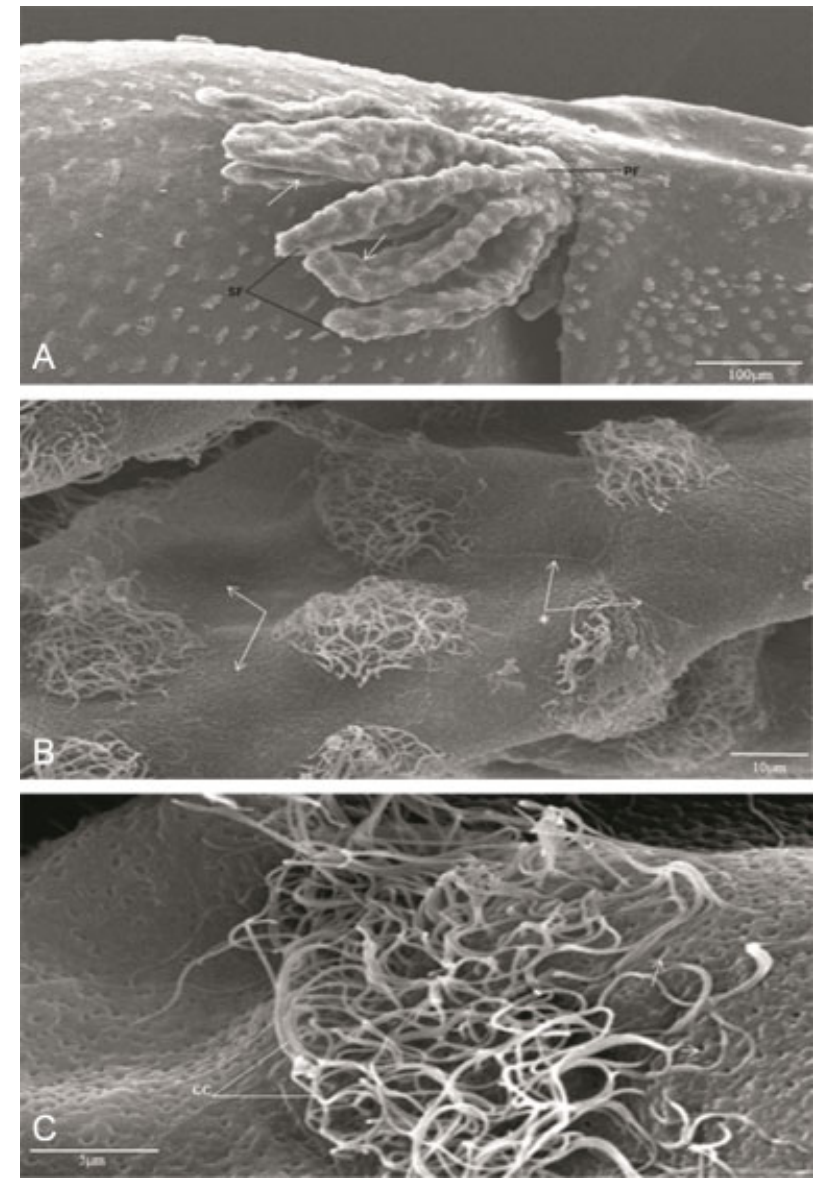

Fig. 8 (A) Scanning electron micrographs of the external gills of Euphlyctis cyanophlyctis tadpoles showing the overlapping and bending of the secondary filaments (SFs) observed after 48 hours of exposure to high pH (arrow). (B) Scanning electron micrographs showing the boundaries of adjacent pavement cells (PVCs) to be affected under high pH (arrow head) along with the boundaries of adjacent PVCs that are not affected $\left({ }^{*}\right)$. (C) Scanning electron micrographs showing the morphology of the ciliated cells (CCs) and the epithelial lesions (arrow).

\section{Discussion}

One of the most important ecological variables guiding the biology of amphibians is water $\mathrm{pH}^{2}$ It affects the breeding, hatching, development, locomotion, mortality and habitat distributions of species. ${ }^{2,26-30}$ Moreover, the variations in acid tolerance of different amphibian species are associated with environmental $\mathrm{pH}$, which indicates that adaptation to acidity does occur among them. ${ }^{26,31}$ Several studies reported that amphibian embryos are less tolerant than larvae to acidity in an aquatic medium. Greater tolerance to acidic $\mathrm{pH}$ has been reported in amphibians as development progresses. ${ }^{4,9}$ Fertilization, embryonic development, hatching, larval development and metamorphosis may be affected by an acidic pH. Egg development ceases within hours after exposure to a very low $\mathrm{pH}^{3,4,32}$ Although larvae do hatch successfully under low $\mathrm{pH}$, the number of developmental abnormalities was found to be high., $4,28,32$ Similar types of abnormalities in response to alkaline and acidic water $\mathrm{pH}$ 

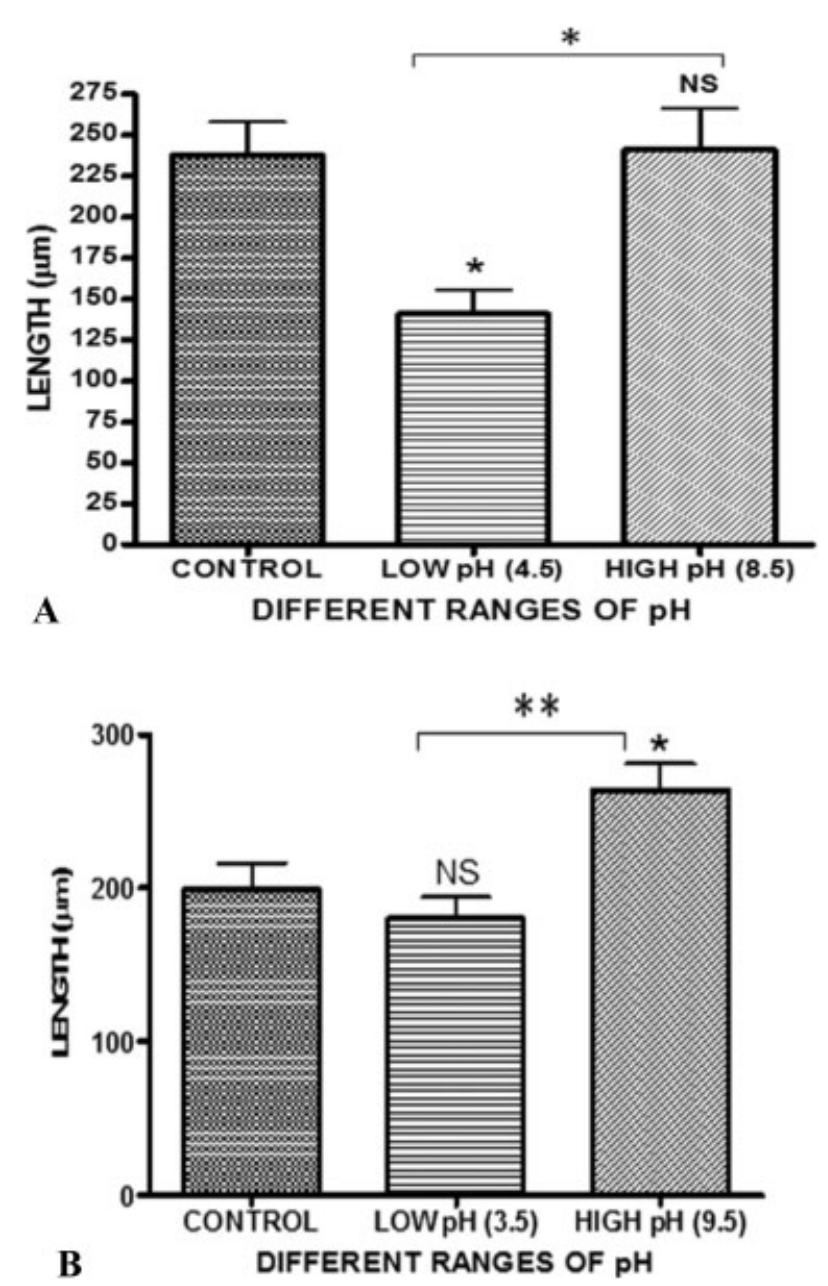

Fig. 9 (A) Length of the secondary filaments (in $\mu \mathrm{m}$ ) in tadpoles of Hyla annectans under the effect of different $\mathrm{pH}$. The error bar represents the standard error (SE). All of the values are expressed as mean \pm standard error of the mean (SEM); $N=5$. The asterisks represent different levels of significance as compared with the values of control: ${ }^{*} p<0.05,{ }^{* *} p<0.01$ and $^{* * *} p<0.001$; NS, not significant at $p>0.05$ respectively. (B) Length of the secondary filaments (in $\mu \mathrm{m}$ ) in tadpoles of Euphlyctis cyanophlyctis under the effect of different $\mathrm{pH}$. The error bar represents the SE. All of the values are expressed as mean $\pm \mathrm{SEM} ; N=5$. The asterisks represent different levels of significance as compared with the values of control: ${ }^{*} p<0.05,{ }^{* *} p$ $<0.01$ and $^{* * *} p<0.001$; NS, not significant at $p>0.05$ respectively.

have been reported in other aquatic animals such as fish. Certain studies have demonstrated that trout that are actively exposed to alkaline $\mathrm{pH}$ develop metabolic alkaloses. ${ }^{33,34}$ In rainbow trout (Salmo gairdneri), waters having high pH promote $\mathrm{CO}_{2}$ excretion, while low $\mathrm{pH}$ inhibits it. ${ }^{35}$ In addition, it has been suggested that high pH inhibits the $\mathrm{Na}^{+}$I $\mathrm{NH}_{4}{ }^{+}$exchange mechanism. ${ }^{36}$

The importance of the gill apparatus in terms of respiration has been discussed by some scholars. ${ }^{37}$ However, there are a few studies on the external gills of tadpoles with regard to the effects of low $\mathrm{pH}^{24,38}$ In fact, no recent reports are available in the existing literature on the effects of low and high $\mathrm{pH}$ on the external gills of anuran tadpoles, except our recent findings. ${ }^{39}$ With regards to $\mathrm{pH}$, studies about the effects of low and high $\mathrm{pH}$ on the oral morphology of
H. annectans, ${ }^{40}$ Polypedates teraiensis and Hylarana leptoglossa tadpoles ${ }^{41}$ have been conducted in our laboratory. It is worthy of mention in this context that the adverse effects of $\mathrm{pH}$ on various tissues of some aquatic organisms such as fish are amply highlighted in the existing literature. Fish exposed to waters with low $\mathrm{pH}(<5.2)$ showed certain morphological alterations that include lifting, sloughing and necrosis of the branchial epithelium; increased mucous secretion; reduced length of the tight junctions between the cells of the branchial epithelium; and distortion of primary and secondary lamellae. ${ }^{42-48}$ Studies on salamander embryos revealed that gastrulation and gill development were truncated in water with low $\mathrm{pH}^{32}$ The latest finding suggested that amphibian gills play a crucial role in oxygen uptake and osmoregulation. ${ }^{37}$ However, it has been suggested that gill damage in amphibian larvae may not be the sole cause of death among the larvae, as oxygen uptake is not merely restricted to the gills; it is also absorbed through the skin. ${ }^{49}$

It should be noted that the comparative morphology of the external gills of some species of anurans has received less attention possibly due to the fact that they do not last long. ${ }^{50}$ Furthermore, it has been suggested that the external gill morphology in anurans exhibits significant diversity at the anatomical and ultra-structural levels. ${ }^{50}$ The present findings on the external gill surfaces in $H$. annectans and $E$. cyanophlyctis support the earlier reports. ${ }^{50}$ The morphological observations made in the current study on the pavement cells, microridges and ciliated cells were similar to those made by other authors on the external gills of Rana dalmatina tadpoles. ${ }^{13}$ There have been many reports on the functional role of the microridged epithelial cells of the primary epithelium. ${ }^{51-54}$ In addition to their role in attaching the mucus produced by the epithelial cells to the gill surface, the microridges of the primary epithelium may stimulate the microturbulence of water. ${ }^{55}$ Various functions have been assigned to the ciliated cells on the surface of amphibian embryos, such as: movement of mucus films; inhibition of micro- organisms and debris attachment; increase in respiratory gas exchange on the surface fluid films by decreasing "dead-space"; enhancement of mobility during prehatching and posthatching gliding; and determination of the quality of water flowing over the external gills. ${ }^{56-59}$ The breakage of cilia on the surface of the gills observed in the current study in response to both low and high $\mathrm{pH}$ suggests that $\mathrm{pH}$ alterations may affect the functions of the gills of the two anuran species studied.

The swellings in the secondary filaments observed in the present study could be due to the entry of solute and water into the matrix. In brook trout (Salvelinus fontinalis) exposed to $\mathrm{pH} 4.5$ and 5.0 for 456 hours, similar results were found: swelling of primary and secondary lamellae; fusion of secondary lamellae; increased mucus production; and thickening and shortening of the secondary lamellae. ${ }^{60}$ Reports of the deleterious consequences of $\mathrm{pH}$ have been meticulously documented in the literature, and gills exposed to toxicants produced similar effects, such as separation and lifting up of the epithelium, which may be considered a defense response. ${ }^{61}$ The swellings in the secondary filament 


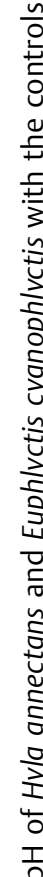

\begin{tabular}{|c|c|c|c|c|c|c|c|c|c|c|c|c|}
\hline & 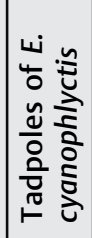 & 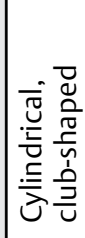 & 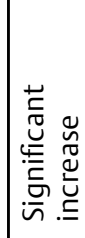 & 을 & 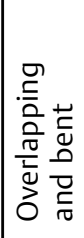 & 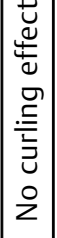 & 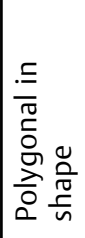 & 올 & 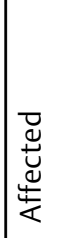 & 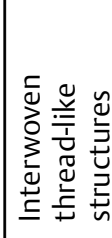 & 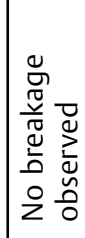 & 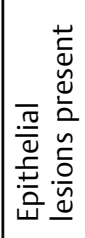 \\
\hline $\begin{array}{l}\frac{T}{2} \\
\frac{5}{5} \\
\frac{5}{I}\end{array}$ & 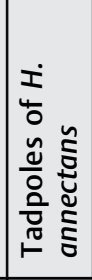 & 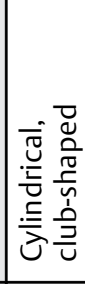 & 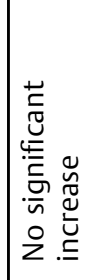 & 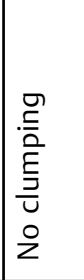 & 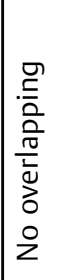 & 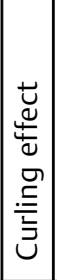 & 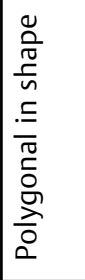 & 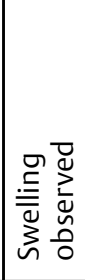 & 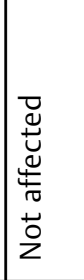 & 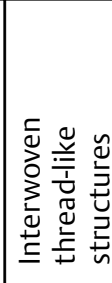 & 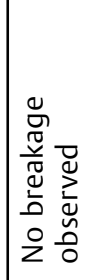 & 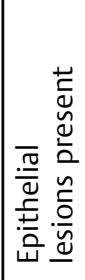 \\
\hline & 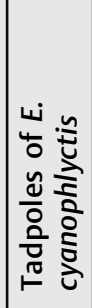 & 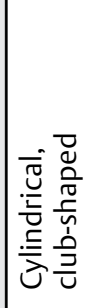 & 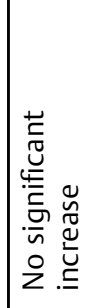 & 을 & 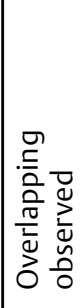 & 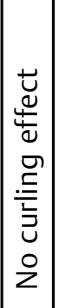 & 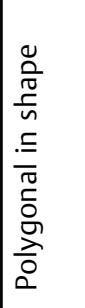 & 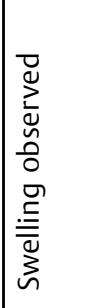 & 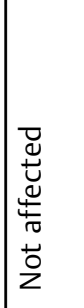 & 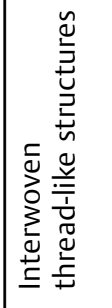 & 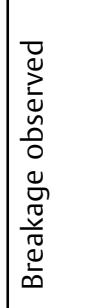 & 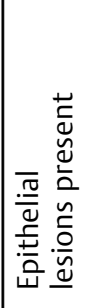 \\
\hline $\begin{array}{l}I \\
\text { I } \\
3 \\
0\end{array}$ & 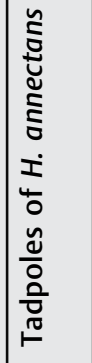 & 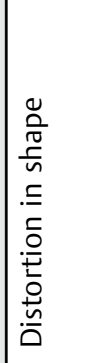 & 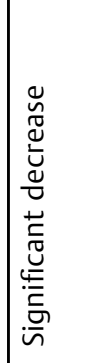 & 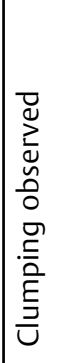 & 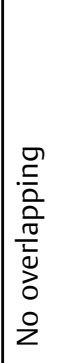 & 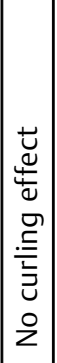 & 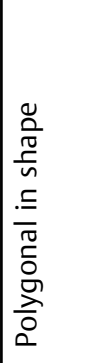 & 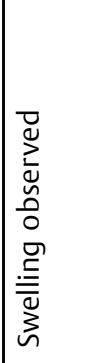 & 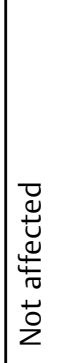 & 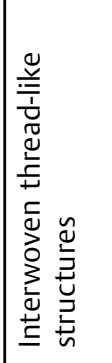 & 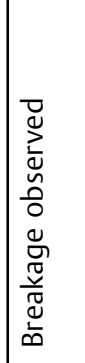 & 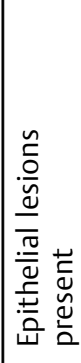 \\
\hline . & 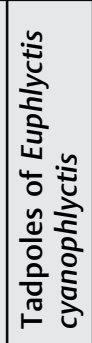 & 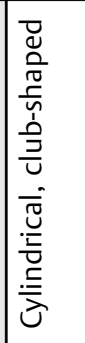 & I & 을 & 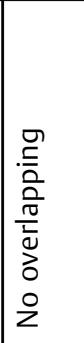 & 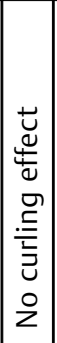 & 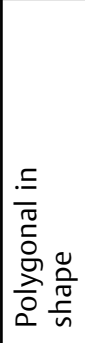 & 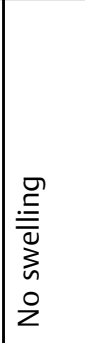 & 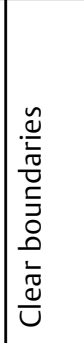 & 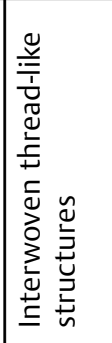 & 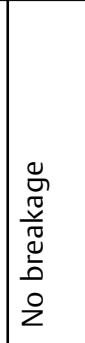 & 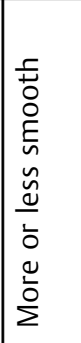 \\
\hline $\begin{array}{l}\frac{n}{0} \\
\frac{0}{2} \\
0\end{array}$ & 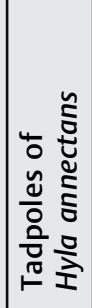 & 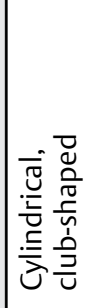 & 1 & 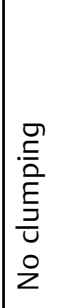 & 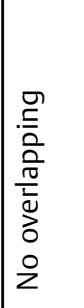 & 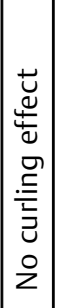 & 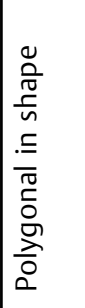 & 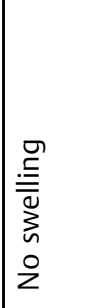 & 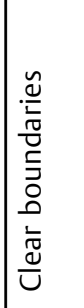 & 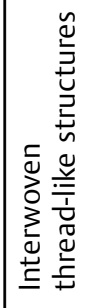 & 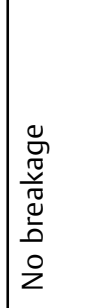 & 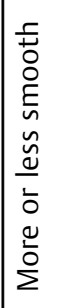 \\
\hline \multirow[b]{2}{*}{ 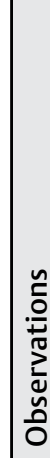 } & \multirow[b]{2}{*}{ 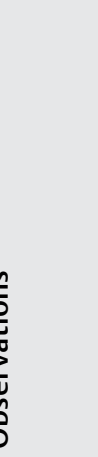 } & 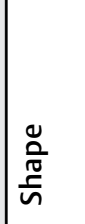 & 吾 & 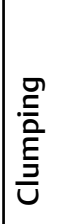 & 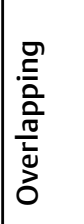 & 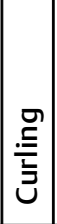 & $\begin{array}{l}\frac{ \pm}{\pi} \\
\frac{\frac{0}{n}}{n}\end{array}$ & 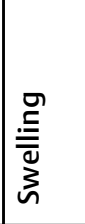 & 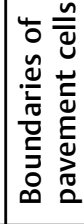 & 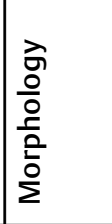 & 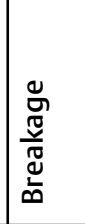 & 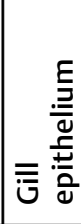 \\
\hline & & \multicolumn{5}{|l|}{ 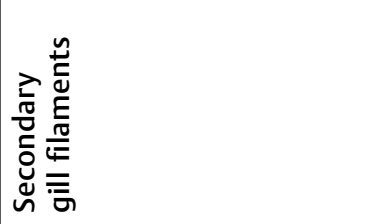 } & \multicolumn{3}{|l|}{ 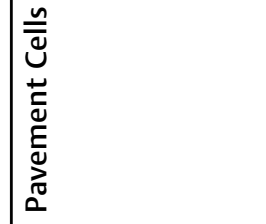 } & \multicolumn{2}{|l|}{$\frac{\stackrel{\pi}{\underline{U}}}{\mathrm{U}}$} & 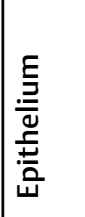 \\
\hline
\end{tabular}


of the gills observed in the present study could be attributed to a decrease in the $\mathrm{Na}^{+}$- and $\mathrm{K}^{+}$- activated ATPase and/or a decline in blood $\mathrm{Na}^{+}$and $\mathrm{Cl}^{-}$concentrations. ${ }^{62}$ The depletion of electrolytes, in particular $\mathrm{Na}^{+}$and $\mathrm{Cl}^{-}$, could bring about lethal iono-/osmoregulatory disruption. ${ }^{63}$ Regarding the occurrence of epithelial lesions in response to low and high $\mathrm{pH}$, we may conclude that it reduced the functional surface of the gill for gaseous exchange, impairing respiratory function. ${ }^{64}$

It should be noted that acidic environments clearly had an effect on natural amphibian populations. ${ }^{9}$ The aforementioned studies revealed that hydrogen ions interfered with sodium flux in amphibian larvae. Sodium uptake was depressed under low $\mathrm{pH}$, and this leads to larval mortality when sodium levels are reduced to $50 \%$. Interspecific variations in larval acid tolerance are related to differences in sodium flux and body sodium content. Alterations in the water $\mathrm{pH}$ also had adverse effects on the morphology of the gill apparatus of the anuran larvae of Litoria fallax. ${ }^{38}$ These included the lifting of the branchial epithelium, necrosis of the integument, and tight junction damage at both the gills and body surface. Similarly, in the present study, changes in water $\mathrm{pH}$ had an effect on the gills and surface epithelium of $H$. annectans and E. cyanophlyctis larvae. These alterations in the morphology of the gills result in altered respiration and iono-/osmoregulation. ${ }^{46,65} \mathrm{~A}$ high sensitivity to acidic $\mathrm{pH}$ resulted in lower survival time and loss of body ions, as observed in fish and amphibians. ${ }^{66}$ The morphological alterations observed in the external gills of $H$. annectans and E. cyanophlyctis in the present study can thus interfere with the respiratory and osmoregulation processes.

The present study provided an understanding of the detrimental effects of low and high $\mathrm{pH}$ among amphibians. Changes in the morphology of the gills could result in respiratory complications, which, in turn, may affect the development and survival of individuals.

\section{Conclusion}

The present study involving SEM revealed several changes in the external gills of $H$. annectans and E. cyanophlyctis larvae exposed to low and high $\mathrm{pH}$. Abnormalities in the arrangement and shape of the gills filaments, and changes in the external gill surface, which included swelling of the gills, epithelial lesions, clumping, breakage of the cilia, and effects on the pavement cell boundaries, were determined. Scanning electron microscopic approaches are relevant in assessing the effects of $\mathrm{pH}$ on the external gills of $H$. annectans and $E$. cyanophlyctis tadpoles.

\section{Acknowledgments}

The authors would like to thank the U.P.E Biosciences Program, University Grant Commission, New Delhi and North Eastern Hill University, Shillong, for the financial support. The facilities provided by the head of the Department of Zoology for us to carry out the research work are highly acknowledged. The authors are also thankful to
SAIF, North-Eastern Hill University, for the scanning electron microscope facility.

\section{References}

1 Andren C, Henrikson L, Olsson M, Nelson G. Effects of pH and aluminium on embryonic and early larval stages of Swedish brown frogs Rana arvalis, R. temporaria and R. dalmatina. Holarct Ecol 1988;11:127-135

2 Barth BJ, Wilson RS. Life in acid: interactive effects of pH and natural organic acids on growth, development and locomotor performance of larval striped marsh frogs (Limnodynastes peronii). J Exp Biol 2010;213(Pt 8):1293-1300

3 Schlichter LC. Low pH affects the fertilization and development of Rana pipiens eggs. Can J Zool 1981;59:1693-1699

4 Pierce BA, Hoskins JB, Epstein E. Acid tolerance in Connecticut wood frogs (Rana Sylvatica). Herpetologia 1984;18:159-167

5 Tome MA, Pough FH. Responses of amphibians to acid precipitation. In T. A. Haines and R. E. Johnson, eds. Acid Rain/Fisheries. American Fisheries Society. , Bethesda, MD, 1982, p. 245-254.

6 Cummins CP. Effects of aluminium and low pH on growth and development in Rana temporaria tadpoles. Oecologia 1986;69 (02):248-252

7 Dunson WA, Conell J. Specific inhibition of hatching in amphibian embryos by low pH. J Herpetol 1982;16:314-316

8 Freda J, Dunson WA. The influence of external cation concentration on the hatching of amphibian embryos in water of low $\mathrm{pH}$. Can J Zool 1985a;63:2649-2656

9 Freda J and DUNSON, WA. Field and laboratory studies of ion balance and growth rates of Ranid tadpoles chronically - exposed to low pH. Copeia 1985b;2:415-423

10 Freda J, Dunson WA. Sodium balance of amphibian larvae exposed to low environmental pH. Physiol Zool 1984;57:435-443

11 McDonald DG, Ozog JL, Simons BP. The influence of low pH environments on ion regulation in the larval stages of the anuran amphibian Rana clamitans.. Can J Zool 1984;62:2171-2177

12 Dietz TH, Alvarado RH. Na and $\mathrm{Cl}$ transport across gill chamber epithelium of Rana catesbeiana tadpoles. Am J Physiol 1974;226 (04):764-770

13 Brunelli E, Perrotta E, Tripepi S. Ultrastructure and development of the gills in Rana dalmatina (Amphibia, Anura). Zoomorphology 2004;123:203-211

14 Nokhbatolfoghahai M, Downie JR. Amphibian hatching gland cells: pattern and distribution in anurans. Tissue Cell 2007;39 (04):225-240

15 Gomez-Mestre I, Tejedo M, Ramayo E, Estepa J. Developmental alterations and osmoregulatory physiology of a larval anuran under osmotic stress. Physiol Biochem Zool 2004;77(02):267-274

16 Khan IA. and KHAN AA. Physico-chemical conductions in Selkha Jheel at Aligarh. Journal of Environmental Ecology 1985;3:269-274

17 Narayani N. Seasonal changes in abiotic parameters of eutrophic wetlands (Lower Lake, Bhopal). In: Shula, A.C., Vandana, A. Trivedi, P.S. and Pandey, S.N. (Eds.), Advances in Environmental Biopollution. A.P. H. Publishing Corporation, New Delhi, 1990, p. 155-163.

18 Chaterjee G, Raziuddin M. Status of water body in relation to some physico-chemical parameters in Asansol Town, West Bengal. Proc Zool Soc India 2006;5:41-48

19 Dutta SK. Amphibians of India and Sri Lanka (Checklist and Bibliography). , Odyssey Publishing House, Bhubaneswar, 1997. p. 55 p.

20 Chanda SK. Handbook of Indian Amphibians. : i-viii, Zoological Survey of India, Kolkata 2002, p. 1-335.

21 Molur S, Walker S. Amphibians of India Report Summary. Zoos Print. XIII 1998;12:1-29

22 GOSNER. KL. A simplified table for staging anuran embryos and larvae with notes on identification. Herpetologica 1960; 16:183-190 
23 Atland A, Barlaup BT. Rate of gastric evacuation in brown trout (Salmo trutta) in acidified and non-acidified water. Water Air Soil Pollut 1991;60:197-204

24 Brunelli E, Tripepi S. Effects of Low pH acute exposure on survival and gill morphology in Triturus italicus larvae. J Exp Zoolog A Comp Exp Biol 2005;303(11):946-957

25 Dey S, Basu BT, Roy B, Dey D. A new rapid method of air-drying for scanning electron microscopy using tetramethylsilane. Journal of Microscopy (Oxford) 1989;156:259-261

26 Freda J and DUNSON, WA. Effects of low pH and other chemical variables on the local distribution of amphibians. Copeia 1986; 2:454-466

27 Gosner KL, Black IH. The effects of acidity on the development and hatching of New Jersey frogs. Ecology 1957;38:256-262

28 Karns DR. Toxic bog water in Northern Minnesota peatlands: ecological and evolutionary consequences for breeding amphibians [thesis]. University of Minnesota, Minneapolis, Minnesota, 1983

29 Pough FH. Acid precipitation and embryonic mortality of spotted salamanders, Ambystoma maculatum. Science 1976;192 (4234):68-70

30 Saber PA, Dunson WA. Toxicity of bog water to embryonic and larval anuran amphibians. J Exp Zool 1978;204:33-42

31 Rowe CL, Sadinski WJ, Dunson WA. Effects of acute and chronic acidification on three larval amphibians that breed in temporary ponds. Arch Environ Contam Toxicol 1992;23(03):339-350

32 Pough FH Wilson RE. Acid precipitation and reproductive success of Ambystoma salamanders. Water Air Soil Pollut 1977; 7:307-316

33 Heming TA, Blumhagen KA. Plasma acid-base and electrolyte status of rainbow trout exposed to alum (aluminum sulphate) in acidic and alkaline environments. Aquat Toxicol 1988; $12: 125-140$

34 Wilkie MP, Wood CM. Recovery from high $\mathrm{pH}$ exposure in rainbow trout: white muscle ammonia storage, ammonia washout and the restoration of blood chemistry. Physiol Zool 1995;68:379-401

$35 \mathrm{Lin} \mathrm{H}$, Randall DJ. The effect of varying water $\mathrm{pH}$ on the acidification of expired water in rainbow trout. J Exp Biol 1990;149: 149-160

36 Wright PA, Wood CM. An analysis of branchial ammonia excretion in the freshwater rainbow trout: effects of environmental $\mathrm{pH}$ change and sodium uptake blockade. J Exp Biol 1985; 114:329-353

37 Brunelli E, Sperone E, Maisano M, Tripepi S. Morphology and Ultrastructure of the gills in two Urodela species: Salamandrina terdigitata and Triturus carnifex. Ita J Zool 2009;76:158-164

38 Meyer EA, Cramp RL, Franklin CE. Damage to the gills and integument of Litoria fallax larvae (Amphibia: Anura) associated with ionoregulatory disturbance at low $\mathrm{pH}$. Comp Biochem Physiol A Mol Integr Physiol 2010;155(02):164-171

39 Devi LM, Thabah CM, Hooroo RNK, Dey S. Scanning electron microscopic studies on the effect of $\mathrm{pH}$ on the gill morphology of Polypedates teraiensis hatchling (Amphibia: Anura). J Adv Microscop Res 2014;9:115-120

40 Thabah CM, Devi LM, HOOROO RNK, DEY S. Microscopic studies on the effects of $\mathrm{pH}$ on the oral morphology of Hyla annectans tadpoles from North East India. J Adv Microscop Res 2014;9(04): $1-6$

40 Devi LM, Thabah CM, Hooroo RNK, Dey S. Morphological and microstructural changes of the oral apparatus in two Anuran tadpoles, in regard to pH. Micron 2016;82:41-51

42 Daye PG, Garside ET. Histopathologic changes in surficial tissues of brook trout, Salvelinus fontinalis (Mitchill), exposed to acute and chronic levels of pH. Can J Zool 1976;54(12):2140-2155

43 Dey S, Kharbuli S. A transmission electron microscopical evaluation of environmental acid stress in a hill stream fish, Devario equipinnatus. National Academy Science Letters (India) 2010; $33: 5-6$
44 Freda J, Sanchez DA, Bergman HL. Shortening of branchial tight junctions in acid-exposed rainbow trout (Onchorhynchus mykiss). Can J Fish Aquat Sci 1991;48:2028-2033

45 Laurent P, Perry SF. Environmental effects on fish gill morphology. Physiol Zool 1991;64:4-25

$46 \mathrm{McDonald}$ DG. The effects of $\mathrm{H}^{+}$on the gills of fresh water fish. Can J Zool 1983;61:691-703

47 Prasad SK, Dey S, Singh OP. A scanning and transmission electron microscopic study on the effect of environmental acid stress on a hill stream fish (Brachydanio rerio) gill. J Adv Microscop Res 2011;6:255-262

48 Rosseland BO, Staurnes M. Physiological mechanisms for toxic effects and resistance to acid water: an ecophysiological and ecotoxicological approach. In: Steinberg, C.E.W Wright, R.F. (Eds.), Acidification of fresh water ecosystems: Implications for the future. John Wiley and sons, London, 1994, p. 227-246.

49 Ultsch GR, Bradford DF, Freda J. Physiology: Coping with the environment. In: McDiarmid R.W., Altig. R (Eds.), Tadpoles: The Biology of Anuran larvae. University of Chicago Press, Chicago, 1999, p. 189-214.

50 Nokhbatolfoghahai M, Downie JR. The external gills of anuran amphibians: comparative morphology and ultrastructure. J Morphol 2008;269(10):1197-1213

51 Hossler FE, Rubey JR, Mcilwain TD. The gill arch of the mullet, Mugil cephalus I. surface ultrastructure. J Exp Zool 1979;208:379-397

52 Hughes GM. Scanning electron microscopy of the respiratory surfaces of the trout gills. J Zool 1979;187:443-453

53 Hughes GM, Umezawa S. Gill structure of the yellow tail and frog fish. J Ichthyol 1983;30:176-183

54 Olsen KR, Fromm PO. A scanning electron microscopy study of secondary lamellae and chloride cells of rainbow trout (Salmo gairdneri). Z Zellforsch Microskopy Anatomy 1973;143:439-449

55 Ojha J, Mishra AK, Munshi JSD. Interspecific variations in the surface ultrastructure of the gills of freshwater Mullets. Jpn J Ichthyol 1987;33:388-393

56 Altig R, Mcdiarmid RW. Body-plan development and morphology. In McDiarmid RW, Altig R (Eds.), Tadpoles: the biology of anuran larvae. University of Chicago Press, Chicago, 1999, p. 24-51

57 Assheton HA. Notes on the ciliation of the ectoderm of the amphibian embryo. QJ Microsc Sci 1896;38:465-484

58 Burggren W. Gas exchange, metabolism, and ventilation in gelatinous frog egg masses. Physiol Zool 1985;58:503-514

59 Kessel RG, Beams HW, Shih CY. The origin, distribution and disappearance of surface cilia during embryonic development of Rana pipiens as revealed by scanning electron microscopy. Am J Anat 1974;141(03):341-359

60 Jagoae $\mathrm{CH}$, Haines TA. Alterations in gill epithelium morphology of yearling Sunapee trout exposed to acute acid stress. Trans Am Fish Soc 1983;112:689-695

61 Ramesh M. Effect of kitazin on the blood chemistry and histopathology of a freshwater fish Cyprinus carpio var. communis. Bharathiar University, Coimbatore, Tamilnadu, India. 1994, p. 1-201.

62 Neiboer E, Richardson RJ. The replacement of nondescript term heavy metals by a biologically and chemically significant classification of metal ions. Environ Pollut 1980;1:3-26

63 Milligan CL, Wood CM. Disturbances in haematology, fluid volume distribution and circulatory function associated with low environmental $\mathrm{pH}$ in the rainbow trout (Salmo gairdneri). J Exp Biol 1982;99:397-415

64 Evans DH, Piermarini PM, Choe KP. The multifunctional fish gill: dominant site of gas exchange, osmoregulation, acid-base regulation, and excretion of nitrogenous waste. Physiol Rev 2005;85 (01):97-177

65 Reid SD. Adaptation to and effects of acid water on the fish gill. In: Hochachka, P.W. Mommsen, T.P.(Eds.), Biochemistry and Molecular Biology of fishes. Elsevier, New York, 1995, vol. 5, p. 213-227.

66 Bohmher J, Rahmann H. Influence of water acidification on amphibians. Fortschr Zool 1990;38:287-309 